\title{
PEMBANGUNAN PENEGAKAN HUKUM PIDANA YANG MENGEFEKTIFKAN KORPORASI SEBAGAI SUBJEK TINDAK PIDANA KORUPSI
}

\section{The Construction of Law Enforcement that Effective of the Corporation as the Subject of Criminal Acts of Corruption}

\author{
Heni Siswanto \\ Fakultas Hukum, Universitas Lampung \\ email: siswanto_heni@yahoo.com
}

\begin{abstract}
The criminal law enforcement policy (PHP), currently associated, corporations as subject's perpetrators of corruption (TPK) include PHP in the formulation stage, the application stage and the execution stage. PHP formulation stage (in abstracto) is based on Article 20 of Law on Corruption which should be a strong legal basis to hold corporations as subjects of TPK, TPK equivalent to the subject of TPK doers of civil servants and individuals. PHP application stage (in concreto) indicates that the corporation as the subject TPK doers very rarely applied / applied to account for the corporation as a principal TPK arguing that criminal sanctions can be imposed is limited; the difficulty of proving corporation fault; the difficulty of law enforcement officers discovered the theory / doctrine and legal basis of corporate errors. Development of PHP policy streamline corporation as the subject doers of TPK in the future related to the renewal of substance, structure and legal culture of corruption and streamline the corporation as a subject the perpetrator TPK. Renewal terms of substance related to the formulation of criminal crime, fault / criminal liability as well as criminal and punishment (strafsoort, strafmat and strafmodus / modaliteit); Renewal in terms of the legal structure of corruption related to the need for law enforcement agencies that further enhance the insight to streamline the corporation as a subject TPK; the need to retain the presence of the Corruption Eradication Commission (KPK); corporate case handling is done by a special team; maximizing the expert testimony; maintain the Police Commission, the Prosecutorial Commission and the Judicial Commission of the role to supervise the conduct of law enforcement. Renewal in terms of legal culture of corruption, which need to be considered more attention to the educational curriculum of character education (mental reform); understanding to the public that corporations as well as TPK subject that needs to be optimized in PHP; anticipation of an attempt to thwart PHP with the corporation as TPK subject to foul play; the issue of jurisdiction, both to
\end{abstract}


those who do and those who receive bribes / gratuities, because they both do TPK.

Keywords: Development, The criminal law enforcement Policies, Corporations, Subject's Perpetrators of Corruption.

\section{abstrak}

Kebijakan penegakan hukum pidana (PHP) saat ini terkait korporasi sebagai subjek pelaku tindak pidana korupsi (TPK) meliputi PHP pada tahap formulasi, tahap aplikasi dan tahap eksekusi. PHP tahap formulasi (in abstracto) didasarkan pada Pasal 20 UU TPK yang seharusnya bisa menjadi dasar hukum yang kuat untuk menjadikan korporasi sebagai subjek TPK, setara dengan subjek pelaku TPK pegawai negeri sipil dan orang perorangan. PHP tahap aplikasi (in concreto) menunjukkan bahwa korporasi sebagai subjek pelaku TPK sangat jarang diterapkan/diaplikasikan untuk mempertanggungjawabkan korporasi sebagai pelaku TPK dengan alasan sanksi pidana yang dapat dijatuhkan bersifat terbatas; sulitnya membuktikan kesalahan korporasi; sulitnya aparat penegak hukum menemukan teori/doktrin dan dasar hukum tentang kesalahan korporasi. Pembangunan kebijakan PHP yang mengefektifkan korporasi sebagai subjek pelaku TPK di masa mendatang terkait pembaharuan substansi, struktur dan budaya hukum pidana korupsi dengan mengefektifkan korporasi sebagai subjek pelaku TPK. Pembaharuan dilihat dari sisi substansi hukum pidana korupsi terkait formulasi tindak pidana, kesalahan/pertanggungjawaban pidana serta pidana dan pemidanaan (strafsoort, strafmat dan strafmodus/modaliteit); Pembaharuan dilihat dari sisi struktur hukum pidana korupsi terkait perlunya lembaga penegakan hukum yang lebih meningkatkan wawasannya untuk mengefektifkan korporasi sebagai subjek TPK; perlunya tetap mempertahankan keberadaan Komisi Pemberantasan Korupsi (KPK); penanganan kasus korporasi dilakukan oleh tim khusus; memaksimalkan keterangan ahli; mempertahankan Komisi Kepolisian, Komisi Kejaksaan, dan Komisi Yudisial yang berperanan untuk mengawasi perilaku penegak hukum; Pembaharuan dilihat dari sisi budaya hukum pidana korupsi, yaitu perlu diperhatikan kurikulum pendidikan yang lebih memperhatikan pendidikan karakter (reformasi mental); pemahaman kepada masyarakat bahwa korporasi juga sebagai subjek TPK yang perlu dioptimalisasikan dalam PHP; antisipasi terhadap upaya untuk menggagalkan PHP dengan korporasi sebagai subjek TPK dengan permainan kotor; persoalan yurisdiksi, baik kepada orang yang melakukan maupun orang yang menerima suap/gratifikasi, karena keduanya sama-sama melakukan TPK. 
Kata Kunci: Pembangunan; Kebijakan PHP; Korporasi; Subjek Pelaku TPK.

\section{A. Pendahuluan}

Penjelasan Umum Undang-Undang Nomor 20 Tahun 2001 tentang Perubahan Undang-Undang Nomor 31 Tahun 1999 tentang Pemberantasan Tindak Pidana Korupsi (UU TPK) disebutkan bahwa korupsi di Indonesia terjadi secara sistematik dan meluas, sehingga tidak hanya merugikan keuangan negara, tetapi juga telah melanggar hak-hak sosial dan ekonomi masyarakat secara luas, maka pemberantasan korupsi perlu dilakukan dengan cara luar biasa.

Pemberlakuan ketentuan peraturan UU TPK didasarkan pada pertimbangan ${ }^{1}$ bahwa tindakan pidana korupsi sangat merugikan keuangan negara atau perekonomian negara dan menghambat pembangunan nasional, sehingga harus diberantas dalam rangka mewujudkan masyarakat adil dan makmur berdasarkan Pancasila dan Undang-Undang Dasar 1945. Akibat tindak pidana korupsi yang terjadi selama ini, juga menghambat pertumbuhan dan kelangsungan pembangunan nasional yang menuntut efisiensi tinggi.

Penegakan hukum pidana pada tahap formulasi/legislasi, UU TPK mengatur paling awal terkait Bab I Ketentuan Umum Pasal 1 ke-1 disebutkan dengan tegas dan terang benderang perihal pengaturan korporasi sebagai subjek hukum tindak pidana korupsi (TPK), mendahului subjek pegawai negeri dan setiap orang yang meliputi orang perseorangan atau termasuk korporasi. Korporasi dimaknai sebagai kumpulan orang dan atau kekayaan yang terorganisasi, baik merupakan badan hukum maupun bukan badan hukum. Pengaturan korporasi sebagai subjek hukum TPK diatur dalam Pasal 20 UU TPK.

Penegakan hukum pidana (PHP) TPK dengan tidak mengefektifkan/ memberdayakan korporasi sebagai subjek hukum TPK dapat dipandang sebagai tindakan diskriminatif pada tahap penerapan/aplikasi subjek TPK korporasi. Subjek TPK korporasi sangat jarang diterapkan. Aparat/pelaku penegak hukum TPK cenderung lebih memilih/mengoperasionalkan subjek TPK berupa pegawai negeri sipil atau orang perseorangan. Padahal, perkara korupsi yang melibatkan korporasi sebagai subjek pelaku TPK cukup banyak. Bahkan, dampak korporasi sebagai pelaku TPK mengakibatkan kerugian keuangan negara dan perekonomian negara jauh lebih besar, lebih berbahaya, lebih merugikan dan lebih tercela dibandingkan dengan pelaku TPK yang dilakukan pegawai negeri sipil dan orang perseorangan.

\footnotetext{
${ }^{1}$ Menimbang a dan b Undang-Undang Republik Indonesia Nomor 31 Tahun 1999 tentang Pemberantasan Tindak Pidana Korupsi.
} 
Tiga persoalan/masalah yang harus dipenuhi dalam hukum pidana yang memungkinkan dapat dijatuhkannya pidana terhadap korporasi sebagai subjek TPK sangat memungkinkan ada. Ketiga masalah pokok hukum pidana, khususnya berkaitan dengan hukum pidana materiil, yaitu meliputi:

a. tindak pidana (strafbaarfeit/criminal act/actus reus);

b. kesalahan (schuld/guilt/mens rea); dan

c. pidana (straf/punishment/poena). ${ }^{2}$

Perbuatan atau tindak pidana korupsi yang dilakukan korporasi yang sangat merugikan keuangan negara dan perekonomian negara, dimungkinkan karena keterkaitan dengan kekuatan dan kekuasaan korporasi terhadap aspek non-hukum meliputi aspek-aspek politik, ekonomi, sosial dan budaya. Oleh karena itu, pada saat untuk mempertanggungjawaban pidana serta pilihan pidana dan pemidanaan terhadap subjek korporasi sebagai pelaku TPK sangat diyakini juga dipengaruhi oleh aspek non-hukum tersebut.

Perbuatan koruptif korporasi dipandang lebih merugikan, lebih berbahaya atau lebih tercela, akan tetapi pada saat penerapan sanksi pidana terhadap korporasi terdapat kendala, misalnya formulasi/rumusan sanksi pidananya bersifat ringan hanya berupa pidana denda yang tidak maksimal; pidana tambahan berupa penutupan (sementara) seluruh atau sebagian perusahaan untuk waktu paling lama 1 (satu) tahun; dan, KUHAP belum mengatur ketentuan hukum acara pidana korporasi.

Kebijakan PHP pada tahap formulasi dan tahap aplikasi yang belum lengkap itu membuat aparat penegak hukum korupsi menjadi kurang bersemangat dalam PHP perkara korupsi pada tahap pelaksanaan/eksekusi. Dampak kelemahan dan kekurangan regulasi TPK ini dimanfaatkan korporasi untuk melakukan perbuatan TPK dan terus melakukan pengulangan karena hukum korupsi dan PHP-nya tidak membuat takut korporasi dan pengurusnya, pilihan jenis pidananya, beratnya pidana dan cara penjatuhan pidananya (strafsoort, strafmaat dan strafmodus/modaliteit) tidak memberikan efek jera. Keadaan ini mendorong untuk terus dilakukannya perbuatan TPK.

Menurut pandangan Ibrahim F.I. Shihata ${ }^{3}$ bahwa upaya penanggulangan korupsi (effort to combat corruption) harus ditempuh

\footnotetext{
${ }^{2}$ Sauer menyebutnya sebagai trias hukum pidana (berupa sifat melawan hukum, kesalahan, dan pidana) dan H.L. Packer (1968: 17) menyebutnya sebagai the three concept atau the three basic problems (berupa offence, guilt, dan punishment). Dikutip dalam Barda Nawawi Arief, Optimalisasi Kinerja Aparat Hukum dalam Penegakan Hukum Indonesia Melalui Pemanfaatan Pendekatan Keilmuan, Makalah disajikan dalam Seminar Nasional Strategi Peningkatan Kinerja Kejaksaan RI, di Gedung Program Pasca Sarjana UNDIP, Semarang tanggal 29 November 2008, hlm. 14.

${ }^{3}$ Ibid., hlm. 264.
} 
melalui "economic reform", "legal and judicial reform", "administrative (civil service) reform", "other institutional reforms", "moral reform", dan "international measures". Khususnya terkait aspek "legal and judicial reform", maka PHP terhadap korporasi sebagai subjek TPK juga berorientasi untuk mempertanggungjawabkan pidana dan pemidanaan terhadap korporasi. Menurut Barda Nawawi Arief $^{4}$ bahwa penempatan korporasi sebagai subjek TPK sangat memungkinkan, mengingat kajian-kajian teoretis (doktrin) sangat mendukung ke arah itu.

Berdasarkan paparan yang telah dikemukakan di atas, maka penelitian ini diarahkan untuk mewujudkan pembangunan PHP yang mengefektifkan korporasi sebagai subjek pelaku TPK. Penelitian ini perlu dilakukan untuk merumuskan/ membangun kebijakan PHP secara integral untuk lebih mengefektifkan korporasi sebagai subjek pelaku TPK. Di masa mendatang, diharapkan korporasi dan subjek TPK pegawai negeri sipil dan orang perseorangan bisa sama-sama diberlakukan secara efektif sebagai subjek hukum TPK untuk pemberantasan, pencegahan dan penanggulangan TPK melalui PHP secara efektif, integral dan berkualitas.

Menurut paparan yang telah dikemukakan di atas, maka dipandang perlu untuk dirumuskan permasalahan penelitian dalam bentuk beberapa pertanyaan penelitian (questions research), yaitu 1) Apakah kebijakan penegakan hukum pidana saat ini terkait korporasi sebagai subjek hukum TPK?; dan 2) Bagaimanakah pembangunan penegakan hukum pidana yang mengefektifkan korporasi sebagai subjek hukum TPK?

Pendekatan masalah yang dipilih untuk membahas permasalahan penelitian digunakan dua pendekatan, yaitu pendekatan yuridis normatif dan pendekatan yuridis empiris. Penelitian ini diperlukan data primer dan data sekunder. Data primer diperoleh dari penelitian empiris terhadap narasumber penelitian yang dipandang relevan dan representatif adalah ahli hukum pidana yang memahami pembangunan PHP dalam pembangunan hukum nasional, sedangkan data sekunder diperoleh dari hasil penelaahan bahan hukum. ${ }^{5}$ Prosedur pengumpulan data dilakukan melalui studi kepustakaan (library research) dan studi lapangan (field research).

\section{B. Pembahasan}

1. Kebijakan Penegakan Hukum Pidana Saat Ini Terkait Korporasi Sebagai Subjek Hukum Tindak Pidana Korupsi

\footnotetext{
${ }^{4}$ Barda Nawawi Arief, Sari Kuliah Perbandingan Hukum Pidana, (Jakarta: Raja Grafindo, 2002), hlm. 131.

${ }^{5}$ Mukti Fajar ND dan Yulianto Achmad, Dualisme Penelitian Hukum Normatif dan Empiris, (Yogyakarta: Pustaka Pelajar, 2010), hlm. 156.
} 
Korupsi di Indonesia terjadi secara sistematik dan meluas, sehingga tidak hanya merugikan keuangan negara, tetapi juga telah melanggar hakhak sosial dan ekonomi masyarakat secara luas, maka pemberantasan korupsi perlu dilakukan dengan cara luar biasa. ${ }^{6}$ Korupsi-korupsi yang dilakukan secara sistematik dapat dilihat dalam kasus Bantuan Likuiditas Bank Indonesia (BLBI) $;{ }^{7}$ Bank Century $;{ }^{8}$ dan Proyek Hambalang, ${ }^{9}$ dan lainlain kasus korupsi yang melibatkan pihak perencana/penganggaran keuangan/pengawas (DPR RI) dan pelaksana proyek (Pemerintah RI); dan kasus-kasus yang melibatkan mantan Menteri Agama RI, SDA; ${ }^{10}$ mantan Ketua Komisi VII DPR RI, SB; ${ }^{11}$ atau mantan Menteri Energi dan Sumber Daya Mineral (ESDM) Kabinet Indonesia Bersatu Jilid II, JW. ${ }^{12}$ Korupsi dikatakan meluas karena terjadi pada hampir setiap institusi Pemerintah (Kementerian, Lembaga dan Pemerintah Daerah), DPR RI dan DPRD serta lembaga yudikatif (Kepolisian, Kejaksaan dan Pengadilan), sehingga telah membuat korupsi sebagai suatu budaya (corruption was a way of life). ${ }^{13}$

${ }^{6}$ Penjelasan Umum Undang-Undang Nomor 20 Tahun 2001 tentang Perubahan Undang-
Undang Nomor 31 Tahun 1999 tentang Pemberantasan Tindak Pidana Korupsi.
Bantuan Likuiditas Bank Indonesia (BLBI) adalah skema bantuan pinjaman BI terhadap
bank-bank yang mengalami krisis likuiditas akibat krisis moneter di Indonesia tahun 1998.
BI telah menyalurkan dana sebesar IDR 147 Triliun kepada 48 bank. Dari hasil audit BPK
telah terjadi penyimpangan sebesar IDR 138 Triliun (http:///www.wikipedia.org/wiki/30 Januari 2011) diakses tanggal 18 Desember 2012.

${ }^{8}$ KPK telah menetapkan 2 orang Deputi Gubernur non-aktif BI, yaitu BM dan SF sebagai tersangka kasus penyimpangan dana talangan (bail out) BI kepada Bank Century. (http://www.kompas.com/read/16 Desember 2012) diakses tanggal 20 Desember 2012.

${ }^{9}$ KPK telah menetapkan beberapa tersangka dalam kasus Proyek Hambalang, dari kalangan pengusaha, anggota DPR, dan pemerintah, serta 1 orang menteri aktif, yaitu AM yang kemudian mengundurkan diri dari jabatannya selaku Menpora.(http://www.kompas. com/read/23 Desember 2012) diakses tanggal 26 Desember 2012.

${ }^{10}$ SDA diduga memanfaatkan dana setoran awal haji oleh masyarakat untuk membiayai pejabat Kementerian Agama dan keluarganya naik haji. KPK juga menduga ada penggelembungan harga terkait katering, pemondokan dan transportasi, Tribun Lampung, Rabu, 29 April 2015.

${ }^{11} \mathrm{SB}$ merupakan terdakwa kasus dugaan penerimaan gratifikasi dalam pembahasan anggaran pendapatan dan belanja negara perubahan di Kementerian Energi dan Sumber Daya Mineral (ESDM), yang menerima uang sebesar 140.000 dolar AS dari mantan Sekjen Kementerian ESDM Waryono Karyo terkait pembahasan dan penetapan APBN-P Tahun Anggaran 2013, Tribun Lampung, Selasa, 28 April 2015.

12 JW telah resmi ditahan oleh Komisi Pemberantasan Korupsi (KPK) sebagai Tersangka terkait penyidikan dugaan dengan maksud menguntungkan diri sendiri atau orang lain secara melawan hukum, atau dengan menyalahgunakan kekuasaannya memaksa seseorang memberikan sesuatu, membayar dengan potongan, atau mengerjakan sesuatu bagi dirinya sendiri pada tahun 2011-2013 di Kementerian ESDM, Lampung Post, Rabu, 6 Mei 2015.

${ }^{13}$ Penelitian Richard Hooley di Filipina yang menggambarkan korupsi terjadi pada setiap intansi pemerintah selama rejim Marcos berkuasa telah membudaya (corruption was a way of life). Lihat Baharuddin Lopa, Kejahatan Korupsi dan Penegakan Hukum, Penerbit Buku KOMPAS, Jakarta, 2001, hlm. 77. Lihat juga Apolinario D. Bruselas, "Corruption: The 
Perhatian dunia internasional terhadap korupsi terlihat dalam Kongres PBB ke-8 tahun 1990 di Havana Cuba yang menyoroti dimensi kejahatan korupsi dalam ..... (3) Corruption terkait economic crime, organized crime, illicit trafficking in narcotic, drugs and psichotropic substances, termasuk juga masalah money laundering..... ${ }^{14}$ Kongres ke- ${ }^{15}$ menyatakan sangat perlunya diperhatikan "corrupt activities of public official":

a. can destroy the potential effectiveness of all types of governmental programmes (dapat menghancurkan efektivitas potensial dari semua jenis program pemerintah);

b. hinder development (dapat menghambat pembangunan); dan

c. victimize individuals and groups (menimbulkan korban bagi individual maupun kelompok).

Hasil Kongres PBB di atas menghimbau kepada negara-negara Anggota PBB untuk menetapkan strategi anti-korupsi sebagai prioritas utama di dalam perencanaan pembangunan sosial dan ekonomi (dokumen A/CONF.144/L.13 disebutkan "The designation of anti-corruption strategies as high priorities in economic and social development plans" serta mengambil tindakan terhadap perusahaan-perusahaan yang terlibat dalam tindak pidana korupsi. ${ }^{16}$

Dokumen Kongres PBB ke-9 tahun 1995 menyatakan korporasi, asosiasi kriminal atau individu mungkin terlibat dalam "penyuapan para pejabat" untuk berbagai alasan yang tidak semuanya bernilai ekonomis, akan tetapi, dalam banyak kasus, masih saja terdapat penyuapan untuk mencapai keuntungan ekonomis. Tujuannya ialah membujuk para pejabat untuk memberikan berbagai bentuk perlakuan khusus/istimewa (preferential treatment) antara lain:

a. memberikan kontrak (awarding a contract);

b. mempercepat atau memperlancar izin (expediting a license);

c. membuat perkecualian-perkecualian atau menutup mata terhadap pelanggaran peraturan (making exceptions to regulatory standards or turning a blind eye to violations of those standards). ${ }^{17}$

Keterlibatan perusahaan-perusahaan (korporasi) dalam TPK bukan rahasia umum lagi. Beberapa kasus yang pernah diproses peradilan pidana

Philipine Experience" dalam (Tokyo: UNAFEI, Resource Material Series No. 52, 1998), hlm. 101.

${ }^{14}$ Arief, Barda Nawawi, Bunga Rampai Kebijakan Hukum Pidana, (Bandung: Alumni, 1996), hlm. 18.

${ }^{15}$ Ibid., hlm. 19.

${ }^{16}$ Terdapat tiga strategi pemberantasan korupsi, yaitu: (1) adanya political will pemerintah;

(2) penyempurnaan penegakan hukum pidana; dan (3) pressure masyarakat.

${ }^{17}$ Ibid., hlm. 20. 
adalah kasus pengusaha besar SHM, ${ }^{18}$ Simulator SIM Mabes POLRI, ${ }^{19}$ IM2 Indosat $^{20}$ dan beberapa kasus yang pelakunya telah dijatuhi pidana seperti kasus Nazarudin $^{21}$ dan Sisminbakum. ${ }^{22}$ Namun dalam praktiknya, penerapan pertanggungjawaban pidana terhadap korporasi sebagai pelaku tindak pidana korupsi jarang dilakukan oleh aparat penegak hukum. Padahal dengan mempertanggungjawabkan korporasi akan didapat manfaat:

a. dapat menimbulkan efek jera terhadap korporasi untuk tidak terlibat dalam tindak pidana korupsi;

b. penegakan hukum pidana akan lebih berkeadilan karena menjangkau pelaku-pelaku lainnya yang turut bertanggungjawab dalam korporasi seperti komisaris, direktur, pegawai, pihak terafiliasi ${ }^{23}$ dan holding company. $^{24}$

c. penjatuhan pidana tambahan yang lebih luas, di samping pembayaran uang pengganti, juga perampasan barang bergerak yang berwujud atau yang tidak berwujud; penutupan seluruh atau sebagian perusahaan; dan pencabutan seluruh atau sebagian hak-hak tertentu atau sebagian keuntungan tertentu yang telah atau dapat diberikan pemerintah. ${ }^{25}$

Menurut Muladi dan Dwidja Priyatno ${ }^{26}$ pembenaran pertanggungjawaban korporasi sebagai pelaku tindak pidana dapat didasarkan hal-hal sebagai berikut:

${ }^{18}$ Pengadilan Tindak Pidana Korupsi Jakarta menyidangkan pengusaha SHM yang diduga melakukan tindak pidana korupsi suap kepada Bupati Buol Amran Batalipu (http://www.metrotvnews.com/13 Desember 2012) diakses tanggal 20 Desember 2012.

19 KPK menahan Irjen (Pol) DS seorang Jenderal Polri aktif sebagai tersangka kasus Simulator SIM Mabes Polri (http://www.tempo.co/ 15 Desember 2012), diakses tanggal 20 Desember 2012.

${ }^{20}$ Penyidik di Kejaksaan Agung melimpahkan berkas perkara tersangka IA dan barang bukti kasus penyalahgunaan frekuensi 2,1 Ghz/3 G PT Indosat Mega Media (IM2) kepada Penuntut Umum di Kejaksaan Negeri Jakarta Selatan (http://www.hukumonline.com/19 Desember 2012), diakses tanggal 26 Desember 2012.

${ }^{21}$ Terdakwa M. Nazarudin divonis pidana penjara 4 tahun 10 bulan oleh Pengadilan Tipikor Jakarta (http://www.bbc.co.uk/20 April 2012) diakses tanggal 22 Desember 2012.

22 Kasus Sisminbakum melibatkan pejabat-pejabat di Kemenkumham RI dan PT SRD (http://www.beritasatu.com/ 20 Juli 2010) diakses tanggal 20 Desember 2012.

${ }^{23}$ Pihak terafiliasi adalah pihak yang turut bertanggungjawab dalam korporasi perbankan, lihat Pasal 40 Undang-Undang Nomor 10 Tahun 1998 tentang Perubahan Undang-Undang Nomor 7 Tahun 1992 tentang Perbankan.

${ }^{24}$ Undang-Undang Nomor 40 Tahun 2007 tentang Perseroan Terbatas, mengatur tentang pertanggungjawaban pemegang saham (Pasal 3).

${ }^{25}$ Eddy Rifai, Pemberantasan Tindak Pidana Korupsi, PPS Magister Hukum Unila, Bandar Lampung, 2002, hlm. 62.

${ }^{26}$ Muladi dan Dwidja Priyatno, Pertanggungjawaban Korporasi dalam Hukum Pidana, (Jakarta: Kencana Prenada Media Group, 2010), hlm. 10. 
a. atas dasar falsafah integralistik, yakni segala sesuatu yang diukur atas dasar keseimbagan, keselarasan, dan keserasian antara kepentingan individu dan kepentingan sosial;

b. atas dasar kekeluargaan dalam Pasal 33 Undang-Undang Dasar 1945;

c. untuk memberantas anomie of success (sukses tanpa aturan);

d. untuk perlindungan konsumen; dan

e. untuk kemajuan teknologi.

Pengaturan pidana tentang pertanggungjawaban pidana korporasi dalam TPK telah diatur dalam peraturan perundang-undangan TPK, tetapi jarang diterapkan dalam praktik. Keengganan Jaksa Penuntut Umum (JPU) mengajukan pelaku korporasi ke pengadilan, karena pemidanaan yang akan dikenakan kepada korporasi hanya berupa pidana denda yang kurang memunyai efek jera dibandingkan dengan pidana mati atau penjara terhadap pelaku orang perorangan dan kesulitan pembuktian "kesalahan" korporasi sebagai bagian unsur melawan hukum daripada membuktikan kesalahan orang-perorang.

Para ahli hukum pidana masih berbeda pendapat, sebagian menyatakan bahwa yang mempunyai kesalahan hanya orang (manusia), sedangkan sebagian lain menyatakan bahwa korporasi juga dapat memunyai kesalahan. Apabila JPU salah dalam membuktikan kesalahan pelaku dalam TPK sebagai kesalahan individu (natuurlijke persoon) dapat berakibat terdakwa diputus bebas (vrijspraak) oleh pengadilan.

Penempatan korporasi sebagai subjek TPK sangat memungkinkan, mengingat kajian-kajian teoretis (doktrin) yang sangat mendukung untuk mempertanggungjawabkan dan memidana korporasi. Menurut Barda Nawawi Arief ${ }^{27}$ diantaranya adalah:

a. Doktrin Pertanggungjawaban Pidana Langsung (direct liabilty doctrine) atau teori identifikasi (identification theory): perbuatan/kesalahan "pejabat senior" (senior officer) diidentifikasi sebagai perbuatan/ kesalahan korporasi. Teori disebut juga dengan teori/doktrin "alter ego" atau "teori organ". Teori ini dapat dimaknai secara sempit (Inggris) adalah hanya perbuatan pejabat senior (otak korporasi) yang dapat dipertanggungjawabkan kepada korporasi; dimaknai secara luas (Amerika Serikat) adalah tidak hanya pejabat senior/direktur, tetapi juga agen di bawahnya;

b. Doktrin Pertanggungjawaban Pidana Pengganti (vicarious liability): bertolak dari doktrin "respondeat superior" ialah a master is liable in certain cases for the wrongful acts of his servant, and a principal for those of his agent"; didasarkan pada "employment principle" bahwa

\footnotetext{
${ }^{27}$ Barda Nawawi Arief, Sari Kuliah Perbandingan Hukum Pidana, (Jakarta: Raja Grafindo, 2002), hlm. 131.
} 
majikan (employer) adalah penanggung jawab utama dari perbuatan para buruh/karyawan; jadi, "the servant's act is the master's act in law"; juga bisa didasarkan pada "the delegation principle". Jadi, "a guilty mind" dari buruh/karyawan dapat dihubungkan ke majikan apabila ada pendelegasian kewenangan dan kewajiban yang relevan (harus ada " $a$ relevan delegation of powers and duties") menurut undang-undang;

c. Doktrin Pertanggungjawaban Pidana (PJP) yang ketat menurut undangundang (strict liability): PJP korporasi dapat juga semata-mata berdasarkan undang-undang, terlepas dari doktrin nomor 1 dan nomor 2 di atas (doktrin "identification" dan doktrin "vicarious liabilty"), yaitu dalam hal korporasi melanggar atau tidak memenuhi kewajiban/ kondisi/situasi tertentu yang ditentukan oleh undang-undang. Pelanggaran kewajiban/kondisi/situasi tertentu oleh korporasi itu dikenal dengan istilah "companies offence", "situational offences", atau "strict liability offences", misalnya undang-undang menetapkan sebagai tindak pidana/delik/offence bagi korporasi yang menjalankan usahanya tanpa izin; korporasi pemegang izin yang melanggar syarat-syarat (kondisi/situasi) yang ditentukan dalam izin itu; korporasi yang mengoperasikan kendaraan yang tidak diasuransikan di jalan umum.

Pendapat dan kajian yang dikemukakan sejumlah kalangan ahli hukum pidana juga mendorong korporasi menjadi subjek TPK secara efektif, dapat dipertanggungjawabkan secara pidana dan penjatuhan pidana; Sedangkan, PHP pada tahap aplikasi (in concreto) bahwa pengaturan/formulasi/rumusan korporasi sebagai subjek pelaku TPK sangat jarang diterapkan untuk mempertanggungjawabkan korporasi sebagai pelaku TPK dengan alasan sanksi pidana yang dapat dijatuhkan pengadilan kepada korporasi bersifat terbatas, tidak boleh berupa pidana mati atau pidana penjara; untuk membuktikan adanya unsur kesalahan korporasi, aparat penegak hukum mengalami kesulitan untuk menemukan teori/doktrin dan dasar hukum tentang kesalahan korporasi karena banyak pertentangan pendapat di kalangan ahli hukum pidana; kekeliruan konstruksi hukum untuk membuktikan korporasi sebagai subjek hukum/pelaku TPK akan berakibat korporasi bisa diputus bebas (vrijspraak) oleh pengadilan.

\section{Pembangunan Kebijakan Penegakan Hukum Pidana yang Mengefektifkan Korporasi sebagai Subjek Hukum Tindak Pidana Korupsi}

Kebijakan $^{28}$ adalah rangkaian konsep dan asas yang menjadi garis besar pelaksanaan suatu pekerjaan, kepemimpinan, dan cara bertindak.

${ }^{28}$ Kuypers menjelaskan bahwa yang dimaksud dengan kebijakan adalah susunan dari (1) tujuan yang dipilih oleh para administrator publik, baik untuk kepentingan diri sendiri 
Kebijakan adalah tindakan secara sadar dan sistematis, dengan mempergunakan sarana-sarana yang cocok dengan tujuan politik yang jelas sebagai sarana yang dijalankan langkah demi langkah. ${ }^{29}$ Dalam hal ini kebijakan terkait hukum pidana dan PHP.

Barda Nawawi Arief ${ }^{30}$ menyatakan bahwa kebijakan hukum pidana (penal policy) dapat mengandung beberapa makna. Kebijakan PHP in abstracto (kebijakan legislasi/formulasi) dan PHP in concreto (khususnya kebijakan aplikasi/penerapan hukum pidana). Dilihat dari kebijakan kriminal (kebijakan penanggulangan kejahatan), hukum pidana bukan merupakan sarana kebijakan yang utama/strategis. Kebijakan yang mendasar/strategis adalah mencegah dan meniadakan faktor-faktor penyebab atau kondisi yang menimbulkan kejahatan. ${ }^{31}$ Walaupun demikian, berbagai kesepakatan internasional masih mengakui perlunya kebijakan hukum pidana diefektifkan, baik pada tahap kebijakan formulasi maupun pada tahap aplikasinya.

Kebijakan PHP terhadap delik korupsi terkesan sekali mendapat prioritas, seimbang dengan upaya pemberantasan tindak pidana lainnya seperti narkoba dan terrorisme. Akan tetapi, penegakan hukumnya lebih berorientasi pada subjek hukum orang-perorangan, bukan korporasi. Kondisi demikian patut dievaluasi, karena tidak mustahil hal itu berdampak pada semakin meningkat dan merebaknya kasus-kasus delik korupsi.

Lemahnya PHP terhadap delik korupsi dengan melibatkan subjek hukum korporas berkaitan erat pula dengan lemahnya kebijakan perundangundangan yang ada. Oleh karena itu perlu dilakukan kajian evaluatif dan reformatif/inovatif/ rekonstruktif untuk mengefektifkan PHP dalam masalah ini.

Upaya melakukan pembaharuan/rekonstruksi pemikiran juridis seyogyanya dilakukan untuk semua bidang PHP. Namun terutama diperlukan dalam menghadapi masalah TPK tidak dapat disamakan dengan

maupun untuk kepentingan kelompok; (2) jalan dan sarana yang dipilih olehnya; (3) saatsaat yang mereka pilih. Menurut Carl Frederik bahwa kebijakan adalah serangkaian tindakan yang diusulkan seorang, kelompok, atau pemerintah dalam suatu lingkungan tertentu dengan menunjukkan hambatan-hambatan dan kesempatan terhadap pelaksanaan usulan kebijakan tersebut dalam rangka mencapai tujuan tertentu, dalam Carl J. Frederik, Man \& His Government, (New York: McGraw Hill, 1963), hlm. 76.

${ }^{29}$ A. Hoorgerwerf, Isi dan Corak-corak Kebajikan, (Jakarta: Erlangga, 1983), hlm. 7.

${ }^{30}$ Barda Nawawi Arief, Kebijakan Hukum Pidana Menghadapi Perkembangan Cyber Crime di Bidang Kesusilaan (Cybersex/Cyberporn), makalah disajikan dalam Seminar Nasional "Cybercrime dan Cybersex/Cyberporn dalam Perspektif Hukum Teknologi dan Hukum Pidana", (Semarang: Kerjasama BPHN dan S2 Hukum UNDIP, 6-7 Juni 2007), hlm. 1.

${ }^{31}$ Dalam berbagai kesepakatan/dokumen internasional dinyatakan, bahwa "Crime prevention strategies should be based on the elimination of causes and conditions giving rise to crime" (Kongres PBB ke-6/1980) atau "The basic crime prevention must seek to eliminate the causes and conditions that favour crime" (Kongres PBB ke-7/1985). 
tindak pidana biasa/konvensional, sehingga tidak bisa dihadapi dengan penegakan hukum dan pemikiran/konstruksi hukum yang konvensional. Asas-asas konvensional dalam hukum pidana positif dan doktrin selama ini meliputi asas legalitas, asas culpabilitas, asas yurisdiksi, alat bukti, dan sebagainya menghadapi tantangan serius untuk diterapkan dalam kasuskasus korupsi.

Rekonstruksi pemikiran juridis lainnya adalah, masalah PHP dalam konteks kebijakan pembaharuan sistem hukum dan pembangunan nasional. Masalah ini patut dikemukakan, karena praktik PHP selama ini terkesan seperti menggunakan "kaca mata kuda". Maksudnya, hanya terfokus pada penerapan ketentuan pidana dalam undang-undang (hukum pidana positif) yang terkait langsung dengan pokok masalah, terlepas dari konteks keseluruhan sistem/ kebijakan nasional.

Padahal, kebijakan hukum pidana (penal policy), baik dalam arti PHP in abstracto dan in concreto, pada hakikatnya merupakan bagian dari keseluruhan kebijakan sistem (penegakan) hukum nasional dan bagian dari upaya menunjang kebijakan pembangunan nasional (national development policy). Hal ini berarti, bahwa PHP in abstracto (pembuatan/perubahan undang-undang-law making/law reform) dan PHP in concreto (law enforcement) seharusnya bertujuan menunjang tercapainya tujuan, visi dan misi pembangunan nasional (bangnas) dan menunjang terwujudnya sistem (penegakan) hukum nasional. Hal ini wajar, karena "criminal/penal policy" merupakan bagian integral dari "social policy".

Kebijakan sistem penegakan hukum pidana (SPHP) secara integralitas sistemik meliputi pembaharuan/pembangunan sistem hukum pidana (penal system reform/development) atau sering disebut secara singkat dengan istilah penal reform. ${ }^{32}$ Dilihat dari sudut sistem hukum (legal system) terdiri dari legal substance, legal structure dan legal culture, maka pembaharuan sistem penegakan hukum pidana secara integralitas sistemik meliputi ruang lingkup yang sangat luas. ${ }^{33}$

Pembaharuan PHP atau digunakan istilah restrukturisasi PHP terhadap korporasi sebagai pelaku TPK, pada hakikatnya merupakan suatu upaya pembaharuan/restrukturisasi keseluruhan sistem hukum pidana korupsi. Barda Nawawi Arief ${ }^{34}$ menjelaskan bahwa istilah restrukturisasi mengandung arti "penataan kembali". Dalam kaitannya dengan menata ulang bangunan sistem hukum pidana Indonesia, maka istilah restrukturisasi sangat dekat dengan "membangun kembali" PHP. Jadi kedua istilah itu

${ }^{32}$ Barda Nawawi Arief, RUU KUHP Baru Sebuah Restrukturisasi/Rekonstruksi Sistem Hukum Pidana Indonesia, (Semarang: Universitas Diponegoro, 2009), hlm. 20.

${ }^{33}$ Ibid., hlm.1.

${ }^{34}$ Barda Nawawi Arief, RUU KUHP Baru Sebuah Restrukturisasi/ Rekonstruksi Sistem Hukum Pidana Indonesia, (Semarang: Universitas Diponegoro, 2009), hlm. 1. 
sangat berkaitan erat dengan masalah law reform dan law development, khususnya berkaitan dengan "pembaharuan/pembangunan PHP (penal enforcement reform/development atau sering disebut secara singkat dengan istilah penal reform).

PHP dilihat dari sudut sistem hukum (legal system) yang terdiri dari legal substance, legal structure dan legal culture, maka pembaharuan penegakan hukum pidana (penal enforcement reform) dapat meliputi ruang lingkup yang sangat luas, yaitu mencakup: ${ }^{35}$

a. pembaharuan "substansi" penegakan hukum pidana meliputi pembaharuan PHP secara "in abstracto" dan "in concreto". Pembaharuan dilihat dari sisi substansi hukum pidana korupsi meliputi pembaharuan hukum pidana materiel, hukum pidana formal dan hukum pelaksanaan pidana di bidang hukum pidana korupsi:

b. pembaharuan "struktur" PHP meliputi antara lain pembaharuan atau penataan institusi/lembaga, sistem manajemen/tatalaksana dan mekanismenya serta sarana/prasarana pendukung dari PHP terhadap korporasi sebagai pelaku TPK:

c. pembaharuan "budaya" PHP meliputi antara lain masalah kesadaran hukum, kepatuhan hukum, perilaku hukum, pendidikan hukum dan ilmu hukum pidana di bidang hukum pidana korupsi, khususnya berkaitan dengan PHP terhadap korporasi sebagai pelaku tindak pidana korupsi.

\section{Penutup}

Kebijakan penegakan hukum pidana (PHP) saat ini terkait korporasi sebagai subjek hukum/pelaku tindak pidana korupsi (TPK) meliputi PHP pada tahap formulasi, tahap aplikasi dan tahap eksekusi. PHP tahap formulasi (in abstracto) didasarkan pada Pasal 20 UU TPK. UU TPK seharusnya bisa menjadi dasar hukum yang kuat untuk PHP pada tahap aplikasi (in concreto). PHP pada tahap aplikasi seharusnya mampu menjadikan korporasi sebagai subjek hukum TPK, setara dengan subjek hukum PNS atau orang-perorangan. PHP tahap aplikasi ternyata menunjukkan bahwa pengaturan korporasi sebagai subjek hukum/pelaku TPK sangat jarang diterapkan untuk mempertanggungjawabkan korporasi sebagai pelaku TPK. Korporasi tidak dijadikan sebagai subjek hukum TPK karena sanksi pidana yang dapat dijatuhkan bersifat terbatas dan sulitnya membuktikan kesalahan korporasi karena sulitnya aparat penegak hukum menemukan teori/doktrin.

Pembangunan kebijakan PHP yang mengefektifkan korporasi sebagai subjek pelaku TPK di masa mendatang terkait pembaharuan di sisi-sisi substansi, struktur dan budaya hukum pidana korupsi dengan

\footnotetext{
${ }^{35}$ Ibid., hlm. 2.
} 
mengefektifkan korporasi sebagai subjek TPK. Pembaharuan dilihat dari sisi substansi hukum pidana korupsi terkait formulasi tindak pidana, kesalahan/pertanggungjawaban pidana serta pidana dan pemidanaan; Pembaharuan dilihat dari sisi struktur hukum pidana korupsi, yaitu perlunya lembaga penegakan hukum lebih meningkatkan wawasannya untuk mengefektifkan korporasi sebagai subjek TPK; perlunya tetap mempertahankan keberadaan Komisi Pemberantasan Korupsi (KPK); penanganan kasus korporasi dilakukan oleh tim khusus; memaksimalkan keterangan ahli; mempertahankan Komisi Kepolisian, Komisi Kejaksaan, dan Komisi Yudisial yang berperanan untuk mengawasi perilaku penegak hukum korupsi; Pembaharuan dilihat dari sisi budaya hukum pidana korupsi, yaitu perlu memperhatikan kurikulum pendidikan yang lebih menekankan pendidikan karakter (reformasi mental); perlu memberikan pemahaman kepada masyarakat bahwa korporasi juga sebagai subjek TPK yang perlu dioptimalisasikan dalam PHP; mengantisipasi terhadap upaya untuk menggagalkan PHP dengan korporasi sebagai subjek TPK melalui permainan kotor seperti budaya uang suap/amplop atau budaya tercela lainnya dan persoalan yurisdiksi TPK.

\section{Daftar Pustaka}

\section{A. Buku}

Arief, Barda Nawawi, 1996, Bunga Rampai Kebijakan Hukum Pidana, Bandung: Alumni.

RUU KUHP Baru Sebuah Restrukturisasi/ Rekonstruksi Sistem Hukum Pidana Indonesia, Badan Penerbit Universitas Diponegoro, Semarang, 2009.

Jakarta: Raja Grafindo. 2002, Sari Kuliah Perbandingan Hukum Pidana,

Bruselas, Apolinario D., 1998, "Corruption: The Philipine Experience" dalam UNAFEI, Tokyo: Resource Material Series No. 52.

Frederik, Carl J., 1963, Man \& His Government, New York: McGraw Hill. Hoorgerwerf, A., 1983, Isi dan Corak-corak Kebajikan, Jakarta: Erlangga.

Lopa, Baharuddin, 2001, Kejahatan Korupsi dan Penegakan Hukum, Jakarta: Penerbit Buku Kompas.

Mukti Fajar ND dan Yulianto Achmad, 2010, Dualisme Penelitian Hukum Normatif dan Empiris, Yogyakarta: Pustaka Pelajar.

Muladi dan Dwidja Priyatno, 2010, Pertanggungjawaban Korporasi dalam Hukum Pidana, Jakarta: Kencana Prenada Media Group.

Rifai, Eddy, Pemberantasan Tindak Pidana Korupsi, 2002, Bandar Lampung: PPS Magister Hukum Unila. 


\section{B. Peraturan Perundang-Undangan}

Undang-Undang Nomor 10 Tahun 1998 tentang Perubahan Undang-Undang

Nomor 7 Tahun 1992 tentang Perbankan.

Undang-Undang Nomor 20 Tahun 2001 tentang Perubahan Undang-Undang

Nomor 31 Tahun 1999 tentang Pemberantasan Tindak Pidana

Korupsi.

Undang-Undang Nomor 40 Tahun 2007 tentang Perseroan Terbatas.

Undang-Undang Republik Indonesia Nomor 31 Tahun 1999 tentang Pemberantasan Tindak Pidana Korupsi.

\section{Internet}

http:///www.wikipedia.org/wiki/30 Januari 2011 diakses tanggal 18

Desember 2012.

http://www.bbc.co.uk/20 April 2012 diakses tanggal 22 Desember 2012. http://www.beritasatu.com/20 Juli 2010 diakses tanggal 20 Desember 2012. http://www.hukumonline.com/19 Desember 2012, diakses tanggal 26

Desember 2012.

http://www.kompas.com/read/16 Desember 2012 diakses tanggal 20

Desember 2012.

http://www.kompas.com/read/23 Desember 2012 diakses tanggal 26

Desember 2012.

http://www.metrotvnews.com/13 Desember 2012 diakses tanggal 20 Desember 2012.

http://www.tempo.co/ 15 Desember 2012, diakses tanggal 20 Desember 2012.

\section{Lain-lain}

Arief, Barda Nawawi, Kebijakan Hukum Pidana Menghadapi Perkembangan Cyber Crime di Bidang Kesusilaan (Cybersex/Cyberporn), makalah disajikan dalam Seminar Nasional "Cybercrime dan Cybersex/Cyberporn dalam Perspektif Hukum Teknologi dan Hukum Pidana", Kerjasama BPHN dan S2 Hukum UNDIP, Semarang, 6-7 Juni 2007.

, Optimalisasi Kinerja Aparat Hukum Dalam Penegakan

Hukum Indonesia Melalui Pemanfaatan Pendekatan Keilmuan,

Makalah disajikan dalam Seminar Nasional Strategi Peningkatan

Kinerja Kejaksaan RI, di Gedung Program Pasca Sarjana Undip,

Semarang tanggal 29 Nopember 2008.

Kongres PBB ke-6/1980

Kongres PBB ke-7/1985.

Lampung Post, Rabu, 6 Mei 2015. 
Tribun Lampung, Rabu, 29 April 2015.

Tribun Lampung, Selasa, 28 April 2015. 